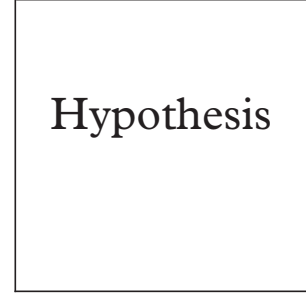

\section{Why common things are common: the tale of non-gonococcal urethritis}

\author{
Mohsen Shahmanesh
}

Common things are common perhaps because they reflect common pathophysiological principles. Non-gonococcal urethritis (NGU) is a common problem. In 1998 over 520000 episodes of NGU were reported from genitourinary medicine clinics in England. ${ }^{1}$ Systematic reviews on its pathogenesis and treatment are long overdue. In their absence it might be useful to list some of what we do know about the aetiology and associations of this common and enigmatic problem.

We know that $30-50 \%$ of men with NGU have a persistent inflammation, ${ }^{2}$ and that even after a course of currently recommended antibiotic therapy the inflammatory stimulus remains for several weeks (months?) in the urethra after chlamydial and non-chlamydial NGU. ${ }^{3}$ We know that chlamydia is isolated from approximately half of patients presenting with their first episode of NGU but less frequently afterwards ${ }^{4}$ and that the proportion with chlamydia negative NGU have apparently increased over the past few years. ${ }^{5}$ The evidence that some cases of chlamydia negative urethritis are associated with Mycoplasma genitalium is now difficult to refute. ${ }^{67}$ A similar role for Ureaplasma urealyticum remains debatable, ${ }^{8}$ and other organisms may account for a further small percentage of other cases. ${ }^{8}$

We know from three separate studies that male contacts of women with bacterial vaginosis (BV) have NGU. ${ }^{9-11}$ We also know that in women BV is associated with plasma cell endometritis, ${ }^{12}{ }^{13}$ premature delivery of the fetus, ${ }^{14}$ and increased proinflammatory cytokines in cervical secretions. ${ }^{15}$ Moreover, the presence of anaerobes may potentiate damage to the fallopian tubes in pelvic inflammatory disease. ${ }^{16}$

We know that men with urethritis of whatever cause (chlamydia, non-chlamydia, or gonococcal) have a greater in vitro lymphocyte proliferative response to chlamydia than controls without urethritis ${ }^{17}$ suggesting that in the presence of mucosal inflammation memory $\mathrm{T}$ cells may be activated through as yet unknown mechanisms with cross reactivity to chlamydial antigens. We are not too surprised by this since we have long known that sterile urethritis (and conjunctivitis) follows infection by a variety of seemingly unrelated micro-organisms at other mucosal sites. ${ }^{18}$

We know that chlamydia causes its damage predominantly through immunological mechanisms ${ }^{8}$ with a role for the ubiquitous $60 \mathrm{kD}$ heat shock protein (hsp 60) family suggested $^{1920}$ and refuted. ${ }^{21}$ We also know that in humans untreated chlamydia can be cleared from tissues. ${ }^{22}$ Finally, although we do have a good human model for studying chlamydial induced tissue damage in the eye, important and lasting genital tissue damage occurs in the female fallopian tube-a relatively inaccessible organ. Hence, most of our information on genital damage by chlamydia comes from animals - with the guinea pig model being the most useful. ${ }^{23}$ Yet data derived from animal models may not be applicable to humans.

It seems reasonable to suggest that NGU might prove a useful model to study not only the mechanisms for the chlamydial inflammatory process but also the mucosal inflammatory response in general. The organ is relatively accessible, and when inflamed its secretions contain sufficient lymphocytes ${ }^{24}$ and macrophages $^{25}$ to study phenotype, cell surface markers, and perhaps cytokine profiles. The lymphocytes are also viable and can be grown in culture from men with urethritis and from controls (without urethritis) ${ }^{26}$ allowing in vitro studies of lymphocyte responses to antigenic stimuli to be performed.

I would propose a hypothesis that at least some cases of non-chlamydial NGU are caused by mechanisms that may involve immune stimulation by one or more components of the vaginal microflora in BV. This hypothesis is open to testing and might provide clues to the immunological damage caused by chlamydia and other organisms in the female genital tract. NGU combines a common condition with an accessible organ. I am surprised so little attention is paid to it.

1 Lamagni T, Hughes G, Rogers P, et al. New cases seen at genitourinary medicine clinics: England 1998. Commun Dis Rep 1999;9(Suppl 6):S3

2 Munday P, Altman DG, Johnson AP, et al. Persistent and recurrent non-gonococcal urethritis without evidence of current infection. Eur F Sex Transm Dis 1982;1:15-19.

3 Lomas DA, Natin D, Stockley RA. Chemotactic activity of urethral secretations in men with urethritis and the effect of treatment. F Infect Dis 1993;167:233-6.

4 Alani MD, Darougar S, MacBurns DC, et al. Isolation of Alani MD, Darougar S, MacBurns DC, et al. Isolation of
Chlamydia trachomatis from the male urethra. Br $\mathcal{f}$ Vener Dis 1977;53:88-92.

5 Zelin JM, Robinson AJ, Ridgway GL, et al. Chlamydial urethritis in heterosexual men attending a genitourinary medicine clinic: prevalence, symptoms, condom usage and partner change. Int $\mathcal{F}$ STD AIDS 1995;6:27-30.

6 Jensen SK, Orsum R, Dohn S, et al. Mycoplasma genitalium: a cause of male urethritis? Genitourin Med 1993;69:265-9.

7 Keane FE, Thomas B, Gilroy C, et al. The association of Chlamydia trachomatis and Mycoplasma genitalium with non-gonococcal urethritis: observation on heterosexual men and their female partners. Int $\mathcal{f}$ STD AIDS 2000;11:435-9.

8 Shahmanesh M. Problems with non-gonococcal urethritis. Int f STD AIDS 1994;5:390-9.

9 Arumainaygam J, DeSilva Y, Shahmanesh M. Anaerobic vaginosis: study of male sexual partners. Int $\mathcal{F}$ STD AIDS vaginosis: study

10 Mitchell SA, Shukla SR, Thin RN. Aetiology of nongonococcal urethritis: a possible relation to other infections. Int $\mathcal{F}$ STD AIDS 1990;1:429-31. 
11 Keane FEA, Thomas B, Whitaker L, et al. An association between non-gonococcal urethritis and bacterial vaginosis and the implications for patients and their sexual partners.

12 Hillier S, Kiviat N, Hawes S, et al. Role of bacterial vaginosis-associated microorganisms in endometritis. $A m$ 7 Obstet Gynecol 1996;175:435-41.

13 Korn AP, Bolan J, Padian N. Plasma cell endometritis in women with symptomatic bacterial vaginosis. Obstet Gynaecol 1995;85:387-90.

14 Hillier SL, Nugent RP, Eschenbach DA. Association between bacterial vaginosis and preterm delivery of low-birth-weight infant. $N$ Engl f Med 1995;333:1737-42.

15 Sturm-Ramirez K, Gaye-Diallo A, Eisen G, et al. High levels of tumor necrosis factor- $\alpha$ and interleukin $1 \beta$ in bacterial vaginosis may increase susceptibility to human immunodeficiency virus. F Infect Dis $2000 ; 182 ; 467-73$.

16 Walker C, Workowski K, Washington AE, et al. Anaerobes in pelvic inflammatory diseases: implications for the centers pelvic infammatory diseases: implications for the centers ment of sexually transmitted diseases. Clin Infect Dis 1999 ; 28:S29-35.

17 Shahmanesh M, Brunst M, Sukthankar A, et al. Peripheral blood $\mathrm{T}$ cell proliferative response to chlamydial organisms in gonococcal and non-gonococcal urethritis and presumed pelvic inflammatory disease. Sex Transm Inf 1999;75:32731.

18 Keat A. Does sterile urethritis occur in Reiter's syndrome secondary to gastrointestinal infection? $\mathrm{Br} \mathcal{F}$ Rheumatol 1992;31:106
19 Brunham RC. Human immunity to chlamydia. In: Stephens RS, ed. Chlamydia: intracellular biology, pathogenesis and RS, ed. Chlamydia: intracellular biology, pathogenesis and

20 Gaston JSH. Immunological basis of chlamydia induced reactive arthritis. Sex Transm Inf 2000;76:156-61.

21 Ward ME. Mechanism of chlamydia-induced disease. In: Stephens RS, ed. Chlamydia: intracellular biology, pathogenesis and immunity. Washington DC: ASM Press, 1999:171210.

22 Morre SA, van den Brule AJC, Rozendale L, et al. A follow-up study of men and women with an asymptomatic Chlamydia trome specimens:prevalence and clearance. In: Saikku P, ed. Proceedings: Fourth Meeting of the European Society for Proceedings: Fourth Meeting of the European Society for Chlamydia

23 Patton DL, Lichtenwalner AB. Animal models of chlamydial infection:update. In: Saikku P, ed. Proceedings: Fourth Meeting of the European Society for Chlamydia Research. Helsinki: Universitas Helsingiensis, 2000:359-61.

24 Shahmanesh M, Round R. Urethral lymphocyte isolation in non-gonococcal urethritis. Genitourin Med 1996;72:362-4.

25 Shahmanesh $M$. Characteristics of inflammatory cells in the urethral smears from men with non-gonococcal urethritis. Genitourin Med 1989;65:18-21.

26 Brunst $M$, Shahmanesh M, Sukthankar A, et al. Isolation and characteristics of $\mathrm{T}$ lymphocytes from the urethra of patients with acute urethritis. Sex Transm Inf 1998;74:27983.

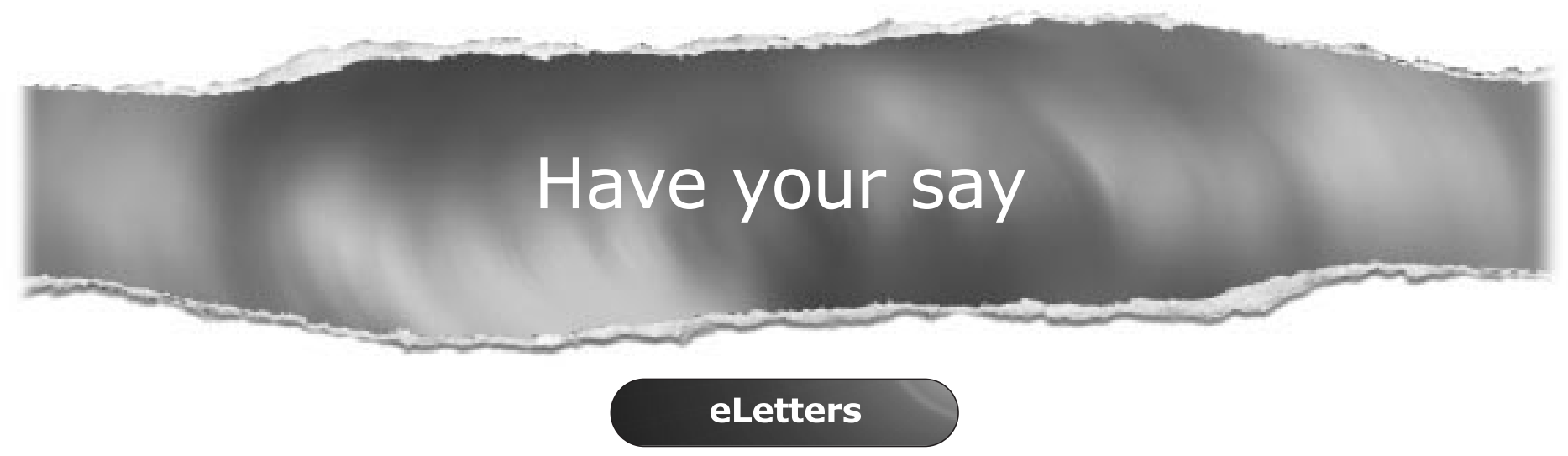

If you wish to comment on any article published in Sexually Transmitted Infections you can send an eLetter using the eLetters link at the beginning of each article. Your response will be posted on Sexually Transmitted Infections online within a few days of receipt (subject to editorial screening).

www.sextransinf.com 